\title{
JOINT STATEMENT ON BILATERALAND REGIONAL COOPERATION BETWEEN MONGOLIA AND THE UNITED STATES OF AMERICA
}

\author{
JANUARY 31, 2004 \\ ULAANBAATAR, MONGOLIA
}

1. Mongolia and the United States of America have developed a cooperative relationship based on shared values and a shared commitment to democracy, a free-market economy, and the global war against terrorism. The two governments express their commitment to expand and deepen their cooperation and close partnership.

2. Mongolia and the U.S. agree that a democratic, secure, and prosperous Mongolia that promotes friendly relations with its neighbors and is an active participant in regional and international economic, political, and security forums is essential to ensuring peace and stability in Asia. The U.S. supports Mongolia's efforts to integrate itself into regional and international economic and financial structures.

3. The U.S. welcomes Mongolia's commitment to combat terrorism and applauds Mongolia's participation in the stabilization and reconstruction of Afghanistan and Iraq . Mongolia expresses appreciation to the U.S. for providing training and expertise to build an internationally qualified peacekeeping capability.

4. The U.S. welcomes Mongolia's ratification of the International Convention on the Suppression of Terrorist Financing and supports its endeavors to fully implement the provisions of the convention, as well as those contained in UNSCR 1373 and all subsequent, related UN and international conventions and resolutions on terrorism.

5. Both sides note the success and positive contribution of the Peace Corps program in Mongolia and look forward to its expansion into the area of comprehensive community development, to focus on rural English education, youth life skills, health and prevention of disease, environmental awareness and economic development. Mongolia and the U.S. note the importance of the Peace Corps' mission to promote world peace and friendship by helping create a better understanding of Americans and Mongolians on the part of both countries' people.

6. Mongolia and the U.S. reaffirm their desire to develop bilateral cooperation in the areas of democracy, human rights, trade, investment, security, 
law enforcement, culture, education, and others, on the basis of mutual respect, mutual benefit, trust and universally recognized principles, including those enshrined in the Charter of the United Nations. Mongolia and the United States agree to hold periodic political consultations at various levels on bilateral and international issues of mutual interest.

7. The U.S. welcomes Mongolia's commitment to democracy and a freemarket economy, which serves as an example for others in Asia. Mongolia expresses its deep appreciation to the U.S. for its long-term support and continued assistance with strengthening democracy and private sector led economic growth. The two governments reaffirm their commitment to work together to promote free and fair elections, representative government, good governance, judicial reform, macro-economic stability, regulatory reform, business development, a healthy civil society, gender equality and prevention of domestic violence.

8. The U.S. reaffirms its willingness to continue bilateral programs of technical assistance consistent with Mongolia's long-term development goals and Mongolia's desire to receive development assistance at a sustainable level and continue its Food for Progress assistance. The US will seriously consider Mongolia's request for eligibility to receive aid under MCA.

9. The U.S. acknowledges Mongolia's efforts to gain internationally recognized and legally binding nuclear weapon-free status to further enhance confidence-building measures in Northeast Asia . Mongolia and the U.S. also note their common support for nuclear weapon-free Korean Peninsula.

10. Mongolia expresses its appreciation for the long-term technical assistance and training provided by the U.S. in the areas of border security, civil defense, and management of humanitarian assistance and disaster relief. The U.S. reaffirms its willingness to further increase its assistance in these areas.

11. Should the U.S. Congress pass legislation to implement the Bush Administration's proposed temporary worker program, the U.S. will seriously consider Mongolia's request to be included in its provisions.

12. Mongolia and the U.S. will expand their cooperation against organized transnational crime, particularly financial crimes such as counterfeiting and money laundering, as well as trafficking in narcotics and in persons. In this regard, the U.S. applauds Mongolia's decision to pass and implement legislation to combat money laundering and to sign, ratify, and implement the provisions of the UN Convention against Transnational Organized Crime and its Protocol 
to Prevent, Suppress, and Punish Trafficking in Persons, Especially Women and Children (Palermo Protocol). The United States and Mongolia agree to explore opportunities for Mongolia to participate in the Financial Action Task Force and other forums and organizations that promote law enforcement cooperation

13. Mongolia and the U.S. recognize and agree that Mongolia's long-term economic and social prosperity depends on more private investment, both domestic and foreign direct investment (FDI), and export-led trade. To this end, Mongolia reaffirms its commitment to improve its overall business and investment climate and export competitiveness by undertaking: to eradicate corruption and sign, ratify and implement the provisions of the UN Convention on Corruption; to professionalize and streamline the civil service bureaucracy; to reform the corporate tax and duty system; to privatize state-owned enterprises; and to ensure legal certainty and investment stability in the minerals, banking/finance, aviation, energy, information technology, and tourism sectors, among others, in order to attract domestic and foreign investment to such sectors. Mongolia and the U.S. reaffirm the importance of effective implementation of the Treaty between the United States of America and Mongolia Concerning the Encouragement and Reciprocal Protection of Investment of October 6, 1994 and the Agreement on Trade Relations, signed in January 23, 1991.

14. The U.S. supports Mongolia's efforts to create an environment conducive to attracting investment, both domestic and foreign and reaffirms its interest in facilitating investment in Mongolia, utilizing, for example, the facilities of the Overseas Private Investment Corporation (OPIC), pursuant to the Investment Incentive Agreement in effect between the United States and Mongolia since 1991, and providing business development assistance to smalland medium-size rural enterprises and to rural labor displaced to urban areas.

15. The two governments agree to undertake exploratory discussions regarding a possible Trade and Investment Framework Agreement (TIFA) and an agreement on the avoidance of double taxation.

16. Done, on , in , in Mongolian and English languages.

For Mongolia Vice Foreign Minister Batbold

For the United States of America Deputy Secretary of State Armitage 